\title{
Public policies to support agroecology in Latin America and the Caribbean
}

\author{
Éric SABOURIN - Jean-François LE COQ - Sandrine FRÉGUIN-GRESH - \\ Jacques MARZIN - Muriel BONIN - Maria Mercedes PATROUILLEAU - \\ Luis L. VÁZQUEZ - Paulo NIEDERLE
}

Latin American agroecology proposes a transformation of conventional agri-food systems. It is driven by social movements that have succeeded in forming coalitions that have promoted its integration into public policies. These policies involve a range of instruments that are often embedded in programmes that also support organic agriculture and sustainable agriculture. However, while these two types of agriculture propose more ecological practices, they do not question the basis of the conventional agri-food system. The implementation of instruments to support agroecology therefore depends on the power relations established within each country. This Perspective analyses these policies and their influence on the development of agroecology in eight countries: Argentina, Brazil, Chile, Costa Rica, Cuba, El Salvador, Mexico, and Nicaragua. These policies remain fragile, while support for large-scale conventional agriculture is still predominant. Their challenge is therefore to convince more broadly farmers, consumers and policymakers about the importance of issues such as public health and food security. $\mathrm{n}$ Latin America and the Caribbean, the model of conventional agriculture, which is characterised by the intensive use of synthetic inputs, a paid workforce and export promotion, has long been the only one targeted by public policies. This model has been criticised by social movements: conducted within a poorly regulated framework, conventional agriculture has had adverse effects on public health, the environment and social equity.

Against this backdrop, alternative forms of agricultural production began to emerge in the 1980s. These include agroecology (agroecología), organic agriculture [agricultura orgánica] and sustainable agriculture [agricultura sostenible) (see table p. 2). Until the 1990s, agroecology was only supported by social movements, which were sometimes backed by international cooperation. Under pressure from these movements, some governments have begun to take into account their proposals and to partially incorporate their demands (see figure p. 3].

Latin American agroecology has become known thanks to the work of researchers such as Miguel Altieri and Stephen Gliessman, and has been taken up by social movements. It proposes a radical transformation of agricultural and food systems and is opposed to the conventional export-oriented model, considering that this transformation is required in order to address environmental and social challenges.
Agroecology shares two principles with organic agriculture: producing while protecting ecosystems and rejecting inputs that are not derived from biological processes. But Latin American agroecology also advocates greater autonomy for producers in upstream and downstream markets and stresses the importance of recycling within agricultural systems. It alters the agri-food system and the relationships between producers and consumers by proposing short value chains and connecting food security and sovereignty at the territorial level. Over and above the technical dimension of agricultural production, agroecology thus provides a holistic approach combining social, environmental, economic and cultural aspects: it thereby defines a new sustainable rural development model.

Governments that are attentive to social movements' criticisms and sensitive to the problems that agroecology hopes to solve have fostered its emergence by proposing specific instruments: this is the case in Cuba, Brazil, El Salvador and Nicaragua.

Organic agriculture, advocated by IFOAM (International Federation of Organic Agriculture Movements], has been adapted to the economic model of conventional agriculture. It differs from it in that it rejects synthetic inputs, which can be replaced by natural products. It imposes specifications that are controlled through a certification process. In the eight countries analysed, organic agriculture is often conducted by 
export-oriented family entrepreneurs or companies, which see certification as a commercial opportunity.

Sustainable agriculture is a more recent alternative that does not question conventional intensification, but introduces agro-ecological practices generally associated with financial support. Sustainable agriculture uses the same supply and marketing channels as conventional agriculture. It is supported by governments concerned by environmental issues, wishing to protect water resources (Mexico, Chile) or to promote a green economy based on ecotourism (Costa Rica). Sustainable agriculture focuses on environmental sustainability, whereas Latin American agroecology also more broadly considers the social pillar.

\section{Circumstances that drive policies towards the promotion of agroecology}

In contexts that vary according to the country, governments have progressively established policies to support agroecology. In all of the cases we have studied, three elements underpin these policies, either independently or simultaneously:

$>$ pressure exerted by social movements (including consumers). These movements mobilise and join forces, sometimes at the regional level, leading to the formulation of policies. This is the case of the coalitions that enabled the development of policies simultaneously promoting agroecology and organic agriculture [Brazil, Nicaragua);

$>$ the search for solutions to economic and environmental crises caused by the specialised agro-industrial model (cotton production in Nicaragua), geopolitical and financial crises the collapse of chemical input import capacity in Cuba and
Nicaragua, the financial crisis in Argentina), or climate events (Hurricane Mitch in Nicaragua);

$>$ partial responses by the public authorities to regional and international challenges: the sustainable rural development act in Mexico [2001); the recognition of environmental benefits (payment for environmental services] applied to agriculture in Costa Rica (2007); the sustainable agriculture plan in Chile [2015).

Despite this progress, agro-ecological production is still scattered and limited. It is marginal, except in Cuba, where it accounts for $65 \%$ of agri-food products. However, it is increasingly acknowledged as a potential way to address the crises affecting conventional agricultural systems.

In order to develop agroecology, public policies are essential at two levels. First, the complexity of productive systems and the diversity of local conditions call for specific technical references to be created locally and disseminated. These references must be underpinned by training and knowledge management systems. Second, in order to offset lower yields and extra production costs, especially for labour, policies must support food processing and marketing. Some products could also be certified according to standards or through direct negotiation between producers and consumers [participatory certification].

So far, dissemination and training efforts have been made by social movements, producers' organisations, technical colleges, universities, non-governmental organisations and, sometimes, public agricultural extension services. However, links with consumers need to be strengthened in order to develop broader coalitions to ensure healthy, environmentally friendly food.

Latin America and the Caribbean: the three alternative agricultural models agroecology, organic agriculture, sustainable agriculture — and the conventional production model.

\begin{tabular}{|c|c|c|c|c|}
\hline Distinctive criteria & $\begin{array}{l}\text { Latin American } \\
\text { agroecology }\end{array}$ & $\begin{array}{l}\text { Organic } \\
\text { agriculture }\end{array}$ & $\begin{array}{l}\text { Sustainable } \\
\text { agriculture }\end{array}$ & $\begin{array}{l}\text { Conventional } \\
\text { agriculture }\end{array}$ \\
\hline Type of farm & $\begin{array}{l}\text { Family farms (known as } \\
\text { peasant, indigenous] }\end{array}$ & All types & All types & All types \\
\hline Trade integration & Limited & Variable & Maximal & Maximal \\
\hline Food system targeted [1] & Short supply chains & $\begin{array}{l}\text { Long supply chains } \\
\text { and export }\end{array}$ & $\begin{array}{l}\text { Long supply chains } \\
\text { and export }\end{array}$ & $\begin{array}{l}\text { Long supply chains } \\
\text { and export }\end{array}$ \\
\hline $\begin{array}{l}\text { Labelling of agri-food } \\
\text { products }\end{array}$ & $\begin{array}{l}\text { Possible, more or less } \\
\text { formalised }\end{array}$ & $\begin{array}{l}\text { Yes, mainly third- } \\
\text { party certification }\end{array}$ & No & No \\
\hline $\begin{array}{l}\text { Scale of change in } \\
\text { agricultural practices }\end{array}$ & $\begin{array}{l}\text { Plot, farm, } \\
\text { territory }\end{array}$ & $\begin{array}{l}\text { Plot, } \\
\text { farm }\end{array}$ & Plot & Plot \\
\hline $\begin{array}{l}\text { Input [ fertilisers, crop } \\
\text { protection products, etc.] }\end{array}$ & $\begin{array}{l}\text { Few inputs, derived from } \\
\text { biological processes }\end{array}$ & $\begin{array}{l}\text { Derived from certified } \\
\text { biological processes }\end{array}$ & $\begin{array}{l}\text { Rational use of } \\
\text { synthetic inputs }\end{array}$ & $\begin{array}{l}\text { Massive use of } \\
\text { synthetic inputs }\end{array}$ \\
\hline $\begin{array}{l}\text { Cultivation of genetically } \\
\text { modified varieties }\end{array}$ & No & No & Yes & Yes \\
\hline $\begin{array}{l}\text { Diversification } \\
\text { of production on farm }\end{array}$ & Yes & Variable & Not a goal & Not a goal \\
\hline $\begin{array}{l}\text { Main factors contributing } \\
\text { to promotion of the model }\end{array}$ & $\begin{array}{l}\text { > Public policies driven by } \\
\text { the social movements } \\
>\text { Consumer demand } \\
\text { through short supply } \\
\text { chains, or preferential } \\
\text { procurement } \\
\text { programmes }\end{array}$ & $\begin{array}{l}>\text { Consumer } \\
\text { demand for } \\
\text { certified organic } \\
\text { products } \\
\text { > Public policies }\end{array}$ & $\begin{array}{l}\text { > Incentive public } \\
\text { policies aimed } \\
\text { at the adoption } \\
\text { of targeted } \\
\text { agricultural } \\
\text { practices }\end{array}$ & $\begin{array}{l}>\text { Agricultural } \\
\text { and trade } \\
\text { policies [free trade } \\
\text { agreements] }\end{array}$ \\
\hline
\end{tabular}

(1): The food system was defined by Louis Malassis: "The way in which people organise themselves to produce, distribute and consume their food" (Malassis L., 1994. Nourrir les hommes. Flammarion, Paris, collection Dominos n 16. ISBN 2080351710). 


\section{Policy instruments to support agroecology}

A wide range of policy instruments are used to promote agroecology in Latin America, yet they are often fragmented between different public sectors. Four types of instruments can be identified, which are related to innovation and knowledge, access to resources, access to markets, and regulation.

Innovation and knowledge management instruments have three objectives: fostering horizontal knowledge sharing and experimentation (Campesino a Campesino programme in Nicaragua, Cuba), developing certain traditional techniques (Mexico, Chile), and promoting territorial agro-ecological knowledge networks (Ecoforte programme in Brazil).

Instruments to ensure access to resources are, following the example of Cuba and Brazil, actions on agrarian reform and land tenure, access to water, access to credit and agricultural extension for family farmers. These actions form solid foundations enabling negotiations on more specific programmes to promote agroecology.

Instruments to ensure access to markets and food security include a broad range of actions. The eight countries studied have organic certification standards, largely to meet the demands of importing countries. Participatory certification systems exist in Costa Rica, Chile and Brazil (where certification through social control, monitored by producer organisations, also exists]. They are also emerging in Cuba. Support instruments for short supply chains are based on the social construction of local markets: fairs, farm boxes, consumer cooperatives, and community farming groups in cities. Other types of short supply chains have been disseminated across Latin America: they include preferential public procurement from family farmers with a premium price for agro-ecological or organic products, such as the food acquisition programme in Brazil and the school food programme in Nicaragua. Finally, urban and peri-urban agriculture programmes (Cuba, ProHuerta programme in Argentina], food security and nutrition programmes (Brazil, Mexico), and the Buen Vivir programme (or Live Well: El Salvador, Nicaragual all foster strong linkages with agroecology.

Environmental regulation and subsidy instruments do not concern only agroecology, but they promote more ecological agricultural practices. They include the regulation of agricultural biodiversity, genetically modified varieties and land use. Programmes to reduce pesticide use exist in Cuba and Costa Rica. Several countries have established subsidies for agricultural practices that protect the environment: this is the case of the recognition of environmental benefits in Costa Rica, the protection of water and biodiversity in Mexico, and energy efficiency in Chile.

\section{Active but complex policy implementation}

The historical analysis of Latin American policies shows the important role played by crises in the emergence of agroecology - economic, geopolitical, environmental and climate crises. The capacity of agroecology to address these crises has been demonstrated, and has made it a real alternative in terms of ecological sustainability and resilience.

However, these policies must overcome major obstacles. They face unfair competition with policies supporting agribusiness. One key challenge is to demonstrate that agroecological production can provide low-cost food for the poorest, an argument also used by agribusiness agriculture. Moreover, it is essential to stress the contributions of agroecology to public health and social equity, rather than just its technical dimensions. Efforts are still needed to better coordinate proposals by social movements supporting agroecology. Indeed, these proposals are undermined by the dominant model, which claims to be the only one able to feed the planet.

The implementation and monitoring of policies to support agroecology are largely dependent on coordination that is currently difficult to establish between different actors and levels: between social movements supporting alternative models and agricultural institutions or public organisations, between ministries and departments, between standards institutions, and finally, between national and territorial governments.

The development of Latin American agroecology will depend on actions designed and planned at the territorial 
level, while today they generally consider only the plot or farm level. The territory corresponds to the relevant level of management of natural resources, landscapes, knowledge networks, and the organisation of local trade. Then, the shift from this local level to the national level requires a coordinated set of specific policies with flexible implementation mechanisms, which have social and territorial roots that are fed by participatory approaches. As exemplified by the cases in
Brazil and Cuba, production and knowledge sharing networks and short supply chains are central to this development.

To convince producers and decision makers, policy instruments to support agroecology need to be flexible and designed at several levels. The territorial level approach is essential to enable producers, consumers and their organisations to adapt these instruments to their specific context.
Perspective $n^{\circ} 45$ presents the main findings of a study of public policies to support agroecology in Latin America and the Caribbean, conducted from 2015 to 2017 within the network on "Public Policy and Rural Development in Latin America and the Caribbean (PP-AL)" (a Platform in partnership for research and training worldwide $P P-A L$, www.pp-al.org/en].

The goal was to analyse the policies and instruments that influence the development of agroecology and to identify their effects and their limitations at the national and local level. A common analysis methodology, relying on secondary data, literature reviews and direct interviews, was used in eight countries: Argentina, Brazil, Chile, Costa Rica, Cuba, El Salvador, Mexico, and Nicaragua.
This research has also led to the following publications:

Fernandes Gabriel B. [Ed.], Romano Jorge 0. [Ed.], 2016. Agroecologia e os objetivos do desenvolvimento sustentável. Agriculturas 13 [3]. http://aspta.org.br/revista-agriculturas.

Rede PP-AL, 2017. Políticas públicas de agroecología na América Latina e Caribe. AS-PTA (Associação Agricultura Familiar e Agroecologia), Rio de Janeiro, 8 p. http://alianzaagroecologia.redelivre. org.br/2017/05/politicas-publicas-para-a-agroecologia-naamerica-latina-e-caribe/.

Sabourin E., Patrouilleau M. M., Le Coq J.-F., Vázquez L., Niederle P.-A. [Eds.], 2017. Políticas Públicas a favor de la Agroecología en América Latina y el Caribe. Porto Alegre, Rede PP-AL, FAO, 412 p. ISBN 978-85-88022-22-5. http://agritrop.cirad.fr/585670.

\section{A few words about...}

Éric Sabourin is a sociologist at CIRAD in the ART-Dev Joint Research Unit (Actors, Resources and Territories in Development, http://art-dev.cnrs.fr/] and a visiting professor at the University of Brasilia, Brazil [Universidade de Brasília, www.unb.br/]).

\section{eric.sabourin@cirad.fr}

Jean-François Le Coq is an agro-economist at CIRAD in the ART-Dev Joint Research Unit and an associate researcher at CIAT in Cali, Colombia (International Center for Tropical Agriculture, http://ciat.cgiar.org/). He coordinates the platform in partnership for research and training PP-AL (Public Policy and Rural Development in Latin America and the Caribbean, www.pp-al.org/en). jflecoq@cirad.fr

Sandrine Fréguin-Gresh is an agro-economist at CIRAD in the ART-Dev Joint Research Unit in Montpellier, France. She works in Nicaragua and Haiti. sandrine.freguin@cirad.fr

Jacques Marzin is an agro-economist at CIRAD in the ART-Dev Joint Research Unit in Montpellier. He works in Cuba and Haiti.

jacques.marzin@cirad.fr

Muriel Bonin is a geographer at CIRAD in the TETIS Joint Research Unit in Montpellier, France (Land, Environment, Remote Sensing and Spatial Information, https://tetis.teledetection.fr/index.php/fr/]. She works in Costa Rica. muriel.bonin@cirad.fr

Maria Mercedes Patrouilleau is a sociologist, and a researcher at INTA in Argentina (Instituto Nacional de Tecnología Agropecuaria, https://inta.gob.ar/). She focuses on public policies and prospective. patrouilleau.mm@inta.gob.ar

Luis L. Vázquez is an agronomist and researcher retired from INISAV in Cuba (Instituto de Investigaciones de Sanidad Vegetal, www.inisav.cu/]. Ilvazquezmoreno@yahoo.es

Paulo Niederle is a sociologist and associate professor at UFRGS in Brazil (Universidade Federal do Rio Grande do Sul, www.ufrgs.br/ufrgs/inicial). pauloniederle@gmail.com

\begin{tabular}{ll}
\hline This article is provi- & To cite this document \\
ded under the terms & Sabourin E., Le Coq J.-F., Fréguin-Gresh S., Marzin \\
of the Creative Com- & J., Bonin M., Patrouilleau M. M., Vázquez L., Niederle \\
mons License CC-BY 4.0: Attribution 4.0 & $\begin{array}{l}\text { P., 2018. Public policies to support agroecology } \\
\text { in Latin America and the Caribbean, CIRAD, }\end{array}$ \\
International (https://creativecommons. & $\begin{array}{l}\text { Montpellier, Perspective 45. } \\
\text { org/licenses/by/4.0/). }\end{array}$ \\
& https://doi.org/10.19182/agritrop/00020.
\end{tabular}

\section{Some links}

Altieri M. A., 2015. Breve reseña sobre los orígenes y evolución de la agroecología en América Latina. Agroecología 10 (2): 7-8. www.socla.co/revista/.

Altieri M. A., 1995. Agroecology: The Science of Sustainable Agriculture. Second Edition. CRC Press, 448 p. ISBN-13 978-0813317182.

Ecoforte, Programa de Ampliação e Fortalecimento das Redes de Agroecologia e Produção Orgânica (programme to develop and consolidate agroecology and organic agriculture networks), Brazil. www.secretariadegoverno.gov.br/iniciativas/brasil-agroecologico/ ecoforte.

Gliessman S. R., 2014. Agroecology: The Ecology of Sustainable Food Systems. Third Edition. CRC Press, 405 p. ISBN-13 9781439895610.

IFOAM, International Federation of Organic Agriculture Movements. www.ifoam.bio/.

ProHuerta programme, Argentina. http://prohuerta.inta.gov.ar. SOCLA, Sociedad Científica Latinoamericana de Agroecología (Latin American Scientific Society of Agroecology). Agroecology in Action. http://agroeco.org/.

\section{RED POLÍTICAS PÚBLICAS Y DESARROLLO RURALE AMERICA LATINA www.pp-al.org/}

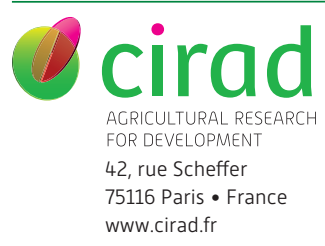

Publication Director: Michel Eddi, CIRAD President Managing Director Editors: Patrick Caron, Office of the Director General in charge of Research and Strategy Cécile Fovet-Rabo Scientific and Technical Information Service Translation: Anna Kiff

Graphic design: Delphine Lavastre-Guard Communication Service Distribution: Christiane Jacquet, Communication Service www.cirad.fr/en/publications-ressources/edition/perspective-policy-brief perspactive ISSN-L 2275-9190 - Email: perspective@cirad.fr

\section{a. M U SE}

MONTPELLIER UNIVERSTIÉD'EXCELLENCE http://muse.edu.umontpellier.fr/ 